\title{
Antecedents and Consequences of Muslim Millennials Attitude Towards Halal Personal Care Products
}

\author{
Febrina Mahliza ${ }^{\mathrm{I}}$, Lucky Nugroho' ${ }^{2}$, Anees Jane $\mathrm{Ali}^{3}$

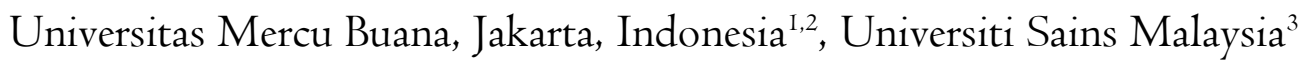 \\ febriana.mahliza@mercubuana.ac.id', \\ lucky.nugroho@mercubuana.ac.id, aneesali@usm.my ${ }^{3}$
}

\begin{abstract}
The millennial population in Indonesia is the majority of the population. Therefore, the millennial population is the target market for all products and services. Furthermore, this study aims to analyze the millennial generation of halal cosmetic products. The method used in this research is quantitative, with primary data taken from I43 millennial generation female consumer respondents in Jakarta and Tangerang. The data collection technique used purposive sampling, while the data analysis used Partial Least Square (PLS). Based on the research results, the millennial generation's attitude towards halal personal care products is significantly influenced by religiosity and halal knowledge.
\end{abstract}

Keywords: Muslim Millenial Attitude, Halal Personal Care Products

\section{A. INTRODUCTION}

Business in the halal industry sector has experienced a significant increase from year to year and has good prospects in the future (Ardiani Aniqoh \& Hanastiana, 2020; Mohd Nawawi et al., 2019). The increase in demand for halal products is contributed by the increasing Muslim population globally, experiencing rapid growth in the past ten years (Hanzaee \& Ramezani, 20I I; Mujahidin, 2020). Also, the phenomenon of the development of digital technology is one of the factors that accelerates the dissemination of information on these halal products (Iqbal Fasa et al., 2020; Nugroho et al., 2020; Wallace, 2018). Important information related to halal products includes security, 
comfort, and the certainty of halal products' availability for the public in general and Muslims in particular (Shafii \& Wan Siti Khadijah, 2012). Current information technology will also increase businesses' added value to improve their business reputation and impact, increasing the company's business turnover (Morsing \& Schultz, 2006). Islam is a comprehensive religion, where Islamic teachings have regulated and provided guidelines related to how a Muslim should behave and act. Thus, a Muslim must carry out his religious teachings in kaffah or totality, including deciding to use cosmetic products (Nugroho, Hidayah, \& Badawi, 2019; Sukmadilaga et al., 2017). However, because Islam is a universal religion and as rahmatan lil alamin or giving benefit to humanity, this halal product is aimed at Muslims and provides goodness and safety for all people (Shafii \& Wan Siti Khadijah, 2012). According to Q.S Al-Anbiya Verse I07: "And We have not sent you, (O Muhammad), except as a mercy to the worlds." Based on this verse, halal products should be used by the adherents of Islam itself and also adherents of other religions (all humanity) who bring grace and prosperity to all of the universes, including animals, plants, especially fellow humans. The importance of carrying out the teachings of Islam has implications for a Muslim's concern for the products he consumes not only limited to halal food and beverage products, but also halal cosmetic and personal care products. Halal cosmetic and personal care products are now a daily necessity not only by women, but also by men (P. Hashim \& Mat Hashim, 2013).

The halal label on cosmetic products is essential and becomes a necessity for sellers to include the halal label on cosmetic products marketed to the public. This phenomenon occurs in a well-known cosmetics sales company in Indonesia, namely Martha Tilaar Group, where Martha Tilaar has a concern about halal certification for her cosmetic products, which impacts increasing sales by $5 \%$ to I0\% (Rahayu \& Tendi, 2019). Thus, halal certification can increase consumer confidence so that consumers are more confident that besides quality products, they also meet the need for halal products. Consumer trust has a vital role in increasing the company's sales turnover ( $\mathrm{Hu}$, Lin, \& Zhang, 2008). On the other hand, there are government regulations on cosmetic products that do not take care of a halal certificate. They cannot attach a halal label and must include a non-halal explanation on the product packaging. Halal certification is essential to ensure raw materials, bulk products, production facilities, product processes are following sharia values (Shirin Asa, 2017). 
Furthermore, the market share of halal products and halal cosmetics in Indonesia is very prospective because the Indonesian Muslim population controls $87.2 \%$ of the world's Muslims (Yoyok \& Hidayat, 2018). Therefore, so that Indonesia is not only a market for cosmetic products with halal labels from other countries, Indonesian halal cosmetic producers must have an adequate strategy so that the products can be of interest to the Indonesian people and the international market (Aisyah, 2016). The majority of cosmetic product users are the younger generation where they also include millennials who were born after I997 or at this time their age range is 17 to 25 years (Ambarwati \& Raharjo, 2018). Likewise, halal cosmetics users, where $65 \%$ of halal cosmetic users are millennials (Febryan \& Kelana, 2020). Furthermore, millennials' motivation to use halal cosmetics is that they want to look beautiful and attractive, but they also want to use cosmetics following Islamic teachings (Majid, Sabir, \& Ashraf, 2015).

Besides that, the phenomenon of public literacy in Indonesia towards Islamic financial services and halal products still needs to be improved. In Indonesia, Islamic financial literacy is still at $16 \%-17 \%$ and far below conventional financial literacy, namely 37-38\% (Ihwanudin et al., 2020). Likewise, literacy of halal products still needs to be improved (Yulianto, 2017). This is because halal product literacy's critical role is crucial, both for producers, sellers, and, of course, for consumers. Based on sharia financial literacy data and literacy data for halal products that still need to be improved, Indonesia's market potential for both halal financial services and halal products such as halal cosmetics still has promising prospects. Therefore, increasing literacy of halal products can increase the demand for halal cosmetics from the public, especially millennials. The decision to buy from consumers comes from their knowledge of the goods' usefulness, which comes from the information they get (Wang \& Hazen, 2016). The development of digital technology is now a necessity for people, especially millennials, to access information quickly and easily. According to Nugroho (2020b), digital-based social media such as Facebook, YouTube, Instagram, WhatsApp, and so on are widely used by the public to find information and compare a product's price.

The millennial generation's attitude towards halal products can be influenced by several things, including religiosity, halal knowledge, and media exposure. In Islam, a Muslim's religiosity is shown from knowledge, understanding, belief, and behavior as a form of obedience to Islamic teachings (Yanti, 2018). Religious life in Indonesia differs from that in other countries. 
Religious life in Indonesia is supported by the government (Asih, Setini, Dharmmesta, \& Purwanto, 2020). The level of religiosity of each individual positively affects halal products' attitudes (Mukhtar, Butt, Mukhtar, \& Butt, 2012). Religiosity has a positive effect on halal products (Adiba, 2019; Clarita, Zimbalist, \& Setiowati, 2020; Larasati, Rahayu, Hati, \& Safira, 2018).

Based on the description above, attitudes towards halal products can be influenced by various factors, including religiosity, halal knowledge, and media exposure. The difference in the results of previous studies makes this research is interested in doing. This research focuses on the study of halal personal care products where the antecedents of the attitudes used are still not widely found in case studies of halal personal care products, especially media exposure variables. Personal care products include lip balm, hand and body lotion, shampoo, body butter, eau de toilette, body mist, roll on, facial wash, facial scrub, face toner, sunscreen gel, oil massage, cream moisturizer, and acne gel (Aisyah, 2017). Therefore the questions in this study are as follows:

- Does religiosity affect attitudes?

- Does halal knowledge affect attitudes?

- Does media exposure affect attitudes?

Furthermore, this attitude can be seen from its influence on purchasing halal personal care products. Research on the millennial generation's attitudes towards halal products is vital because the millennial generation is a potential market for the halal industry both now and in the future. This research is expected to be an input for business players in Indonesia's halal personal care industry to determine what variables can increase the millennial generation's attitudes towards purchase intention in halal personal care products. In the end, this can be an effort to encourage Indonesia to rise to the first position in the market for halal cosmetics and personal care in the world.

\section{B. THEORETICAL}

\section{Religiosity and Attitude}

Muslim activities in daily life must be following Islamic law, which comes from the Koran, hadiths, and other sources of Islamic law. They must be balanced with knowledge in implementing it in everyday life, called the Tawhid String Relations (Choudhury, 2018; Nugroho, 2020a). Furthermore, religiosity is described as the extent to which a person adheres to religious values, beliefs, and uses them in everyday life (Worthington et al., 2003). Religiosity consists of two 
components: adherence to certain groups called religious affiliation. The second component is a religious commitment, which describes how committed a person is to religious beliefs and priorities and uses it daily. Religiosity is a person's appreciation of religion, which involves symbols, beliefs, values, and behaviordriven by spiritual power, complex integration of religious knowledge, feelings, and religious actions within a person (Astogini, Wahyudin, \& Wulandari, 20I I).

In Islam, a Muslim's religiosity is shown from knowledge, understanding, belief, and behavior as a form of obedience to Islamic teachings (Yanti, 2018). Religiosity can be reflected through implementing the five daily prayers, reading the Holy Quran, fasting in the month of Ramadan, and paying zakat (Adiba, 2019). Religiosity can also be reflected by reading religious books and watching religious programs (Abd Rahman, Asrarhaghighi, \& Ab Rahman, 2015). Based on the description, the following hypothesis can be formulated:

$\mathrm{HI}=$ Religiosity has a positive effect on attitudes.

\section{Halal Knowledge and Attitude}

Consumer knowledge is an essential asset to a company's business. This is because knowing consumer knowledge is the first step for a company to develop its business by developing and improving the quality and features of products and services to meet customers' needs and wants (Rowley, 2002). Furthermore, consumer knowledge is all information that consumers have regarding products and services and other information related to these products and services. Besides, a definition states that consumer knowledge is related to changes in individual or consumer behavior due to consumers' experience in using the product or service (Kotler \& Pfoertsch, 2007). Knowledge refers to facts, feelings, or experiences known to a person or group of people (Abd Rahman et al., 2015). Knowledge is a person's abilities and expertise, in theory, or practice, received from others (Briliana \& Noviana, 2016). Muslim individuals are guided by sharia law to uphold knowledge of halal principles that describe what can be consumed and what cannot be consumed (Suki \& Salleh, 20I8).

An individual's halal knowledge will be different from the halal knowledge possessed by other individuals. Halal knowledge can be reflected through halal and haram knowledge, sufficient knowledge to distinguish between prohibited and permitted materials based on Islamic law, knowledge of inputs, processes, and halal products' impacts (Adiba, 2019). Halal knowledge can also be reflected 
through halal certification (Abd Rahman et al., 2015). Based on the description above, the following hypothesis can be formulated:

$\mathrm{H} 2$ = Halal knowledge has a positive effect on attitudes.

\section{Media Exposure and Attitude}

According to Yulianti (2016), a lack of information will reduce public interest in using a company or organization's products or services. So that information has a vital role in making decisions to choose goods or services according to your needs and desires. Consumers are looking for information to fulfill their information needs. Consumers get information about halal products through exposure to mass media such as television, radio, magazines, and the internet (Ambali \& Bakar, 20I4). Media is a communication medium and the most influential tool in seeking information towards the development of modern society today because the media itself can shape society's 'reality' because of its ability to change people's emotions (Tulloch \& Zinn, 20I I).

Exposure to halal products through the media is significant to improve because it can educate Indonesian consumers about the concept of halal and halal products. Electronic media exposure plays an essential role in influencing Muslim attitudes towards halal products (Kamarulzaman, Veeck, Mumuni, Luqmani, \& Quraeshi, 2015). Media exposure can be reflected in the role of mass media in facilitating the provision of information about halal products, the role of mass media in the adequacy of providing information about halal products, and the role of mass media in the effectiveness of providing an understanding of halal products (Kurniawati \& Savitri, 2019). Based on the description, the following hypothesis can be formulated:

H3 = Exposure affects attitudes.

\section{Attitude}

Positive knowledge will impact increasing the interest of potential users of products and services to use them. Therefore according to Kotler (I994), the intention is a person's situation before taking action, which can be used as a basis for predicting a person's behavior or attitude. For example, an interest in partnering with an Islamic bank is assumed to be an interest in using Islamic bank products and services, an attitude that appears as a response to an object that indicates a consumer's desire to use it (Nugroho et al., 2020; Sudirman et al., 2020). Attitude is a positive or negative individual feeling about behavior (Ajzen 
\& Fishbein, 1972). Furthermore, attitude is an expression of feelings, reflecting feelings of pleasure or displeasure with an object (Rohmatun \& Dewi, 2017). A very positive attitude towards halal products has a positive effect on their intention to buy halal products (Mukhtar et al., 20I2). Someone will tend to have more "intention" to do something if the activity is something he likes (Endah, 2014). Attitudes towards an object can affect the processing of related information, judgments, and the resulting behavior (Larasati et al., 2018). Attitudes can be reflected in halal products' preference, looking for halal labels on products, assuming that halal products are essential (Briliana \& Mursito, 2017). Attitudes can also be reflected in one's own choice to use halal products and halal products by essential people in the surrounding environment (Abd Rahman et al., 2015; Adiba, 2019). Nevertheless, figure I is the research model and hypothesis:

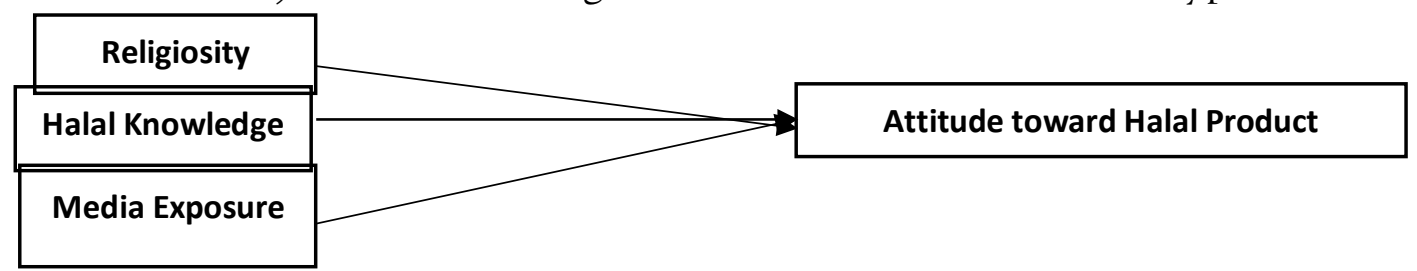

Figure I. The Conceptual Framework of Research

\section{METHODOLOGY Research Design}

This study is causal research that explains the effect of religiosity, halal knowledge, and media exposure as independent variables toward attitude as the dependent variable. This research used quantitative and qualitative approaches. This approach was chosen because it can provide an overview of the millennial generation's attitude towards halal products.

\section{Variables Definition and Operationalization}

The variables used in this study consist of religiosity, halal knowledge, media exposure, and attitudes. Religiosity, halal knowledge, media exposure, and attitudes are latent variables that are difficult to be measured directly and need manifest variables as indicators (Ghozali \& Latan, 2015). The following are the definitions and operational variables that use the Likert Scale I-7 as a measurement scale (Table I). 


\section{Table I. Variables Definition and Operationalization}

\begin{tabular}{|c|c|c|}
\hline Variables & Definition & Indicators \\
\hline Religiosity & $\begin{array}{l}\text { Religiosity is a person's appreciation } \\
\text { of religion, which involves symbols, } \\
\text { beliefs, values, and behaviors driven } \\
\text { by spiritual power, complex } \\
\text { integration of religious knowledge, } \\
\text { feelings, and religious actions within } \\
\text { a person (Adiba, 2019). }\end{array}$ & $\begin{array}{l}\text { I. the routine of pray five times a day } \\
\text { 2. the routine of reading the Holy Quran } \\
\text { 3. the routine of fasting in Ramadhan } \\
\text { 4. the routine of paying zakat } \\
\text { 5. the routine of reading religious books } \\
\text { 6. the routine of watching religious programs }\end{array}$ \\
\hline $\begin{array}{l}\text { Halal } \\
\text { Knowledge }\end{array}$ & $\begin{array}{l}\text { Halal knowledge is knowledge about } \\
\text { the halalness of a product that is tied } \\
\text { to facts, feelings and experiences felt } \\
\text { by someone (Abd Rahman et al., } \\
\text { 20I5) }\end{array}$ & $\begin{array}{l}\text { I. understanding of lawful and haram } \\
\text { 2. sufficient knowledge to distinguish between } \\
\text { prohibited and permitted materials based on Islamic } \\
\text { law } \\
\text { 3. enough knowledge of the input, process, and impact } \\
\text { of halal products } \\
\text { 4. understanding that halal products have halal } \\
\text { certification }\end{array}$ \\
\hline $\begin{array}{l}\text { Media } \\
\text { Exposure }\end{array}$ & $\begin{array}{l}\text { Media exposure is reflected in the } \\
\text { role of the mass media in providing } \\
\text { information about halal products } \\
\text { easily, sufficiently, and effectively for } \\
\text { the public's understanding of halal } \\
\text { products (Kurniawati \& Savitri, } \\
\text { 2019) }\end{array}$ & $\begin{array}{l}\text { I. the ease of providing information about halal } \\
\text { products } \\
\text { 2. the adequacy of providing information on halal } \\
\text { products } \\
\text { 3. the effectiveness of providing an understanding of } \\
\text { halal products }\end{array}$ \\
\hline Attitude & $\begin{array}{l}\text { Attitude is a person's preference for } \\
\text { using halal personal care products } \\
\text { (Abd Rahman et al., 20I5) }\end{array}$ & $\begin{array}{l}\text { I. preference for choosing halal personal care products } \\
\text { 2. look for the halal label on the personal care products } \\
\text { carefully } \\
\text { 3. the assumption that halal products are important } \\
\text { 4. the use of halal products is one's own choice } \\
\text { 5. influential people in the environment carry out the } \\
\text { use of halal products. }\end{array}$ \\
\hline
\end{tabular}

\section{Population and Sample}

This research population comprises women who live in Jakarta and Tangerang, aged 20-40 years. This study used purposive sampling techniques with several criteria, namely (I) born between 1980 and 2000, (2) Muslim, (3) female, (4) have never bought and used local brand halal personal care products that use halal brand positioning such as Wardah.

The minimum sample size in SEM analysis is 100 to 200 samples with 5 to 20 times the indicators (Sekaran \& Bougie, 2016). Thus to fulfill the theory's recommendations above, the number of samples is 154 respondents $(7 \times 22$ indicators). However, there is respondent data that is double-fold so that the number of respondent data that can be used is I 43 respondents. 
IKONOMIKA

Volum 5, No 2 (2020)

\section{Method of Analysis}

This study used partial least square (PLS) as the analysis method. Partial least square can be used in the study to predict where it does not require many assumptions, such as the data must be normally distributed or the sample is large. (Ghozali \& Latan, 20I5). Partial least square consists of the outer model, which explains the relationship between the observed items and the latent variables. The inner model explains the relationship between the latent variables.

\section{RESULTS AND DISCUSSION}

\section{Respondent Profile}

The number of respondents in this study was I43 millennial generations of women who live in Jakarta and Tangerang. The collection of data using online questionnaires from April to June 2020. The following are the profiles of respondents (Table 2 ).

Table 2. Respondent Profile

\begin{tabular}{|c|c|c|}
\hline Parameters & Quantity & Percentage \\
\hline \multicolumn{3}{|l|}{ Domicile } \\
\hline Jakarta & $9 \mathrm{I}$ & $63.63 \%$ \\
\hline Tangerang & 52 & $36.36 \%$ \\
\hline \multicolumn{3}{|l|}{ Status } \\
\hline Single & 106 & $74.13 \%$ \\
\hline Married & 37 & $25.87 \%$ \\
\hline \multicolumn{3}{|l|}{ Age } \\
\hline $20-25$ & I03 & $72.03 \%$ \\
\hline $26-30$ & 24 & $\mathrm{I} 6.78 \%$ \\
\hline $3 I-35$ & $\mathrm{I} 4$ & $9.79 \%$ \\
\hline $36-40$ & 2 & $1.40 \%$ \\
\hline \multicolumn{3}{|l|}{ Occupation } \\
\hline College Student & 80 & $55.94 \%$ \\
\hline Housewife & I5 & $10.50 \%$ \\
\hline Private Employee & 39 & $27.27 \%$ \\
\hline Entrepreneur & 8 & $5.59 \%$ \\
\hline Government Employee & I & $0.70 \%$ \\
\hline \multicolumn{3}{|l|}{ Education } \\
\hline Senior High School & 80 & $55.94 \%$ \\
\hline Diploma & 3 & $2.10 \%$ \\
\hline Bachelor Degree & 42 & $29.37 \%$ \\
\hline Master Degree & 17 & II.89\% \\
\hline Doctoral Degree & $\mathrm{I}$ & $0.70 \%$ \\
\hline
\end{tabular}


Antecedents and Consequences of Muslim Millennials Attitude Towards Halal Personal Care Products

Febrina Mahliza ${ }^{1}$, Lucky Nugroho², Anees Jane $\mathrm{Ali}^{3}$

Total I43 $100,00 \%$

Respondents are people who never purchased and used halal personal care products from local brands using halal brand positioning. Based on Table 3, respondents are dominated by people aged 20-25 years as many as I03 people $(72.03 \%)$, with the majority of them are single as 106 people (74.13\%). The respondents are dominated by college students, as many as 80 people (55.94\%). The latest educational background is dominated by high school education/equivalent, as many as 80 people (55.94\%).

\section{Results of Partial Least Square Analysis}

Outer Model Testing

The outer model is used to analyze the convergent validity and discriminant validity. Indicators are valid if the outer loading values of each indicator are above 0.7 (Figure 2).

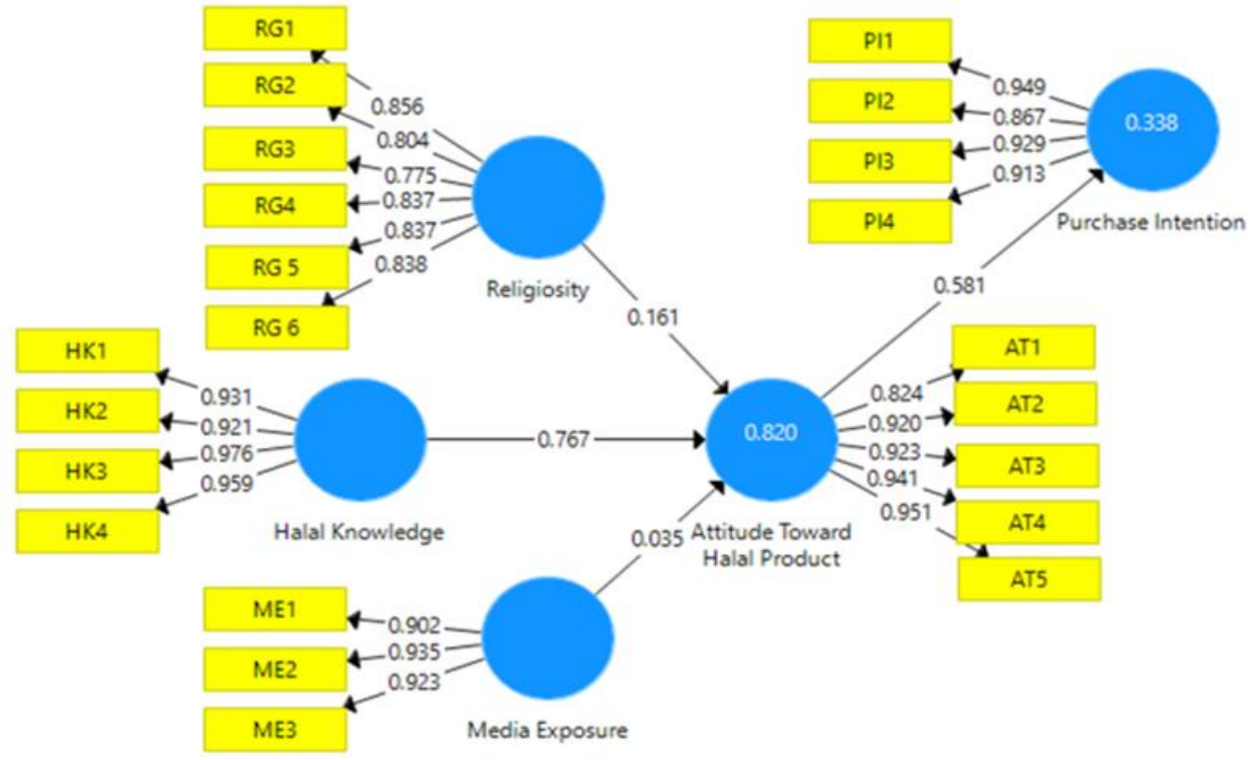

Figure 2: Outer loadings

Based on Figure 2, all indicators are valid because the values of outer loading are above 0.7 . For discriminant validity, the values of AVE must be above 0.5 , and the value of AVE's square root must be compared with the correlation between constructs (Table 3) 
IKONOMIKA

Volum 5, No 2 (2020)

Table 3. The Fornell-Larcker Criterion

\begin{tabular}{lcccc}
\hline & Attitude Toward & $\begin{array}{c}\text { Halal } \\
\text { Knowledge }\end{array}$ & $\begin{array}{c}\text { Media } \\
\text { Exposure }\end{array}$ & Religiosity \\
\hline Attitude Toward (AT) & $0.9 \mathrm{I3}$ & & & \\
Halal Knowledge (HK) & 0.897 & 0.947 & & \\
Media Exposure (ME) & 0.621 & 0.664 & 0.920 & 0.825 \\
Religiosity (RG) & 0.688 & 0.665 & 0.480 & 0.8505 \\
\hline
\end{tabular}

Based on Table 4, discriminant validity is achieved because AVE's square values are more significant than those in the column and row. All values of AVE are also above 0.5 (Table 4). Besides, the Composite Reliability value and Cronbach's Alpha value must be above 0.7 to show that the constructs are reliable (Ghozali, 20I4).

Table 4. Composite Reliability, Cronbach's Alpha, AVE

\begin{tabular}{cccc}
\hline Constructs & Cronbach's Alpha & Composite Reliability & AVE \\
\hline Attitude Toward & 0.949 & 0.953 & 0.833 \\
Halal Knowledge & 0.962 & 0.963 & 0.897 \\
Media Exposure & 0.909 & 0.910 & 0.846 \\
Religiosity & 0.909 & 0.929 & 0.680 \\
\hline
\end{tabular}

Based on Table 3, all constructs are reliable because the values of Composite Reliability and Cronbach's Alpha are above 0.7. It can be concluded that all criteria in the outer model are fulfilled.

\section{Inner Model Testing}

Hypothesis testing for the outer model by looking at the p-value below 0.05 and the t-statistic is more significant than the t-table value. If the p-value is below 0.5 , and the t-statistic is more significant than I,65I, it can be concluded that exogenous variables significantly affect endogenous variables (Table 5).

Table 5. Path Coefficient

\begin{tabular}{lcccc}
\hline \multicolumn{1}{c}{ Relationship } & Construct Coefficients & T-Statistic & P-Value & Results \\
\hline $\mathrm{HK} \rightarrow$ AT & 0.767 & I4.5I & 0.000 & Significant \\
$\mathrm{ME} \rightarrow$ AT & 0.035 & 0.604 & 0.273 & Not Significant \\
$\mathrm{RG} \rightarrow$ AT & $0.16 \mathrm{I}$ & 2.965 & 0.002 & Significant \\
\hline
\end{tabular}

Based on Table 5, religiosity positively affects attitudes (construct coefficient value $0.16 \mathrm{I}$ ) and significant (p-value $002<0.05$ ). Halal knowledge positively affects attitudes (construct coefficient value 0.767 and significant ( $\mathrm{p}$ - 
value $0.000<0.05$ ). Media exposure positively affects attitudes (construct coefficient value of 0.035 ) but not significant ( $p$-value $0.273>0.05$ ).

The second test on the inner model can be seen from the R-Square results where it is a goodness-fit model test (Table 6). R-Squares represent the amount of variance of the constructs described by the model.

Table 6: R-Square

\begin{tabular}{cc}
\hline Constructs & R-Square \\
\hline Attitude Toward & 0.820 \\
\hline
\end{tabular}

Based on Table 6, the R-Square value of attitude is 0.820 . It means that the variability of halal products' attitudes can be explained by the construct of religiosity, halal knowledge, and media exposure is $82.0 \%$. Simultaneously, the remaining $18.0 \%$ is explained by other variables not examined in the model.

\section{Effect of Religiosity on Attitudes}

Religiosity positively affects attitudes. The effect of religiosity on attitudes has proven significant. This shows that religiosity affects the attitude of the millennial generation towards halal personal care products. The millennial generation's attitude towards halal personal care products will be higher if the religiosity of the millennial generation is getting higher.

This result is consistent with the research results of Adiba (2019), Briliana \& Noviana (2016), and Larasati et al., (2018). Religiosity acts as an antecedent of attitude, which positively affects attitudes. The higher a person's religiosity, the higher his/her attitude towards halal products.

In Islam, a Muslim's religiosity is shown from knowledge, understanding, belief, and behavior as a form of obedience to Islamic teachings (Yanti, 2018). The level of religiosity of each individual positively influences halal products' attitudes (Mukhtar et al., 2012). The level of religiosity has succeeded in influencing consumer attitudes towards halal products. The more religious a person is, the more he will behave towards halal products (Larasati et al., 2018).

In this study, religiosity is reflected through the implementation of praying five times a day (RGI), reading the Holy Quran (RG2), fasting in the month of Ramadan (RG3), paying zakat (RG4), reading religious books (RG5) and watching the religious programs (RG6). Implementing the five daily prayers is the indicator that contributes the most in measuring the millennial generation's religiosity. Millennial Muslim generations feel that the routine of carrying out the 
five daily prayers is behavior-driven by spiritual forces. They adhere to religious values and beliefs and use them in everyday life by implementing the five daily prayers.

Islamic teachings require followers to carry out all activities based on religious rules throughout their life (Saeed, Ahmed, \& Mukhtar, 200I). The five daily prayers are the pillars of Islam. This also implements the five daily prayers as the most dominant indicator in reflecting religiosity, positively affecting their attitude towards halal personal care products. Religious consumers will seek broader insights and information about halal products, influencing the demand for halal products (A. J. C. M. Hashim \& Musa, 2013).

\section{Effect of Halal Knowledge on Attitudes}

Halal knowledge positively affect attitudes. The effect of halal knowledge on attitudes is proven to be significant. This shows that halal knowledge affects the attitude of the millennial generation towards halal personal care products. The millennial generation's attitude towards halal personal care products will be higher if the millennial generation's halal knowledge is getting higher.

This result is consistent with the research results of Adiba (2019), Briliana \& Noviana (2016), and Larasati et al., (2018). Halal knowledge acts as an antecedent of attitude, which positively affects attitudes. The higher a person's halal knowledge, the higher his attitude towards halal products. The consumers who have much knowledge will influence their attitude in evaluating a product's attributes (Adiba, 2019).

Knowledge is related to the facts, feelings, or experiences of a person or group (Abd Rahman et al., 2015). An individual's halal knowledge can be different from the halal knowledge possessed by other individuals. In this study, halal knowledge is reflected through the understanding of Islamic law regarding halal and haram (HKI), sufficient knowledge to distinguish between prohibited and permitted materials based on Islamic law (HK2), knowledge of the input, process, and impact of halal products (HK3) and knowledge of halal certification (HK4). Knowledge of the input, process, and impact of halal products is the indicator that contributes the most in measuring halal knowledge.

Muslim individuals are guided by sharia law to uphold knowledge of halal principles that describe what can be consumed and what cannot be consumed (Suki \& Salleh, 2018). This shows that the millennial Muslim generation has sufficient knowledge about halal products related to inputs, processes, and 
impacts. The millennial generation who have halal knowledge will further influence their attitude towards halal personal care products. This is because consumers who understand more about halal products will potentially carry out real behavior purchasing halal products (Farlina, Shafii, \& Shahwan, 2015).

\section{Effect of Media Exposure on Attitudes}

Media exposure positively affects attitudes. However, the effect of media exposure on attitudes is not proven to be significant. This shows that media exposure positively affects the millennial generation's attitude towards halal personal care products, but the effect is not proven significant. The greater the exposure of media about halal personal care products, it is not followed by the millennial generation's attitudes towards halal personal care products.

Media exposure is considered to influence halal products (Bin Nawawi, Bt. Mohd. Roslin, Hamid, \& Bt. Abdul, 2016). Consumers get information about halal products through media exposure, such as television, radio, magazines, and the internet (Ambali \& Bakar, 20I4). However, this result is not consistent with the research result of Kamarulzaman et al. (2015). This study cannot prove that media exposure plays an essential role in influencing a person's attitudes towards halal products.

Although it does not significantly affect, the media exposure variable will not be eliminated from the model. Overall, the components of this variable still help form a good model. In this research, media exposure is reflected in the ease of providing information about halal products (MEI), the adequacy of providing information about halal products (ME2), and the effectiveness of providing an understanding of halal products (ME3). The adequacy of providing information on halal products is the indicator that contributes most (dominantly) in measuring media exposure.

The millennial generation feels that the information provided in the mass media, both online and offline, is sufficient. The millennial generation is considered a generation with high interaction with online media, especially social media. The millennial generation grows up in the digital era (Kaifi, Nafei, Khanfar, \& Kaifi, 2012). The millennial generation is also considered a generation that consumes consumption, which is influenced by virtual friends' thoughts on social media (Ordun, 2015). However, this does not guarantee that media exposure affects their attitude towards halal personal care products. 
IKONOMIKA

Volum 5, No 2 (2020)

\section{E. CONCLUSION}

This study aims to analyze the factors that influence attitudes towards halal personal care products.

- Religiosity positively and significantly affect the attitude of the millennial generation towards halal personal care products;

- Halal knowledge positively and significantly affect the attitude of the millennial generation towards halal personal care products;

- Media exposure positively affects the attitude of the millennial generation towards halal personal care products. 


\section{REFERENCES}

Abd Rahman, A., Asrarhaghighi, E., \& Ab Rahman, S. (2015). Consumers and halal cosmetic products: Knowledge, religiosity, attitude and intention. Journal of Islamic Marketing, 6(I), I48-I63. https://doi.org/I0.II08/JIMA-09-20I3-0068

Adiba, E. M. (2019). Consumer Purchasing Behavior of Halal Cosmetics: A Study on Generations X and Y. Journal of Islamic Monetary Economics and Finance, 5(I), I69-192. https://doi.org/I0.2I533/isjss.v2iI.52

Aisyah, M. (2016). Consumer Demand on Halal Cosmetics and Personal Care Products in Indonesia. Al-Iqtishad: Journal of Islamic Economics, Q I), I25-I42. https://doi.org/I0.I5408/aiq.v9iI.I867

Aisyah, M. (2017). Consumer Demand on Halal Cosmetics and Personal Care Products in Indonesia. Al-Iqtishad: Journal of Islamic Economics, 9 I), I25-I42. https://doi.org/I0.I5408/aiq.v9iI.I867

Ajzen, I., \& Fishbein, M. (I972). Attitudes and normative beliefs as factors influencing behavioral intentions. Journal of Personality and Social Psychology, 2I(I), I-9. https://doi.org/I0.I037/h003I930

Ambali, A. R., \& Bakar, N. A. (20I4). People's Awareness on Halal Foods and Products: Potential Issues for Policy-Makers. Procedia - Social and Behavioral Sciences, I2I(20I4), 3-25. https://doi.org/I0.I0I6/j.sbspro.20I4.0I.II04

Ambarwati, A., \& Raharjo, S. T. (2018). Prinsip Kepemimpinan Character of A Leader pada Era Generasi Milenial. PHILANTHROPY: Journal of Psychology, 2(2), I I4. https://doi.org/I0.26623/philanthropy.v2i2.I I5I

Ardiani Aniqoh, N. A. F., \& Hanastiana, M. R. (2020). Halal Food Industry: Challenges and Opportunities in Europe. Journal of Digital Marketing and Halal Industry, 2(I), 43. https://doi.org/I0.21580/jdmhi.2020.2.I.5799

Asih, D., Setini, M., Dharmmesta, B. S., \& Purwanto, B. M. (2020). Religiosity and spirituality: Conceptualization, measurement and its effect on frugality. Management Science Letters, IO, 4023-4032. https://doi.org/I0.5267/j.ms1.2020.7.007

Astogini, D., Wahyudin, \& Wulandari, S. Z. (20I I). Aspek Religiusitas dalam Keputusan Pembelian Produk Halal. Jeba, I3(I), I-8.

Bin Nawawi, S., Bt. Mohd. Roslin, R., Hamid, \& Bt. Abdul, N. (2016). Customers' Intention to Repurchase Halal Personal Care Products: The 
IKONOMIKA

Volum 5, No 2 (2020)

Moderating Role of Religiosity. In International Business Research 2nd Advances in Conference ABRIC20I6 (pp. 39-54).

Briliana, V., \& Mursito, N. (2017). Asia Paci fi c Management Review Exploring antecedents and consequences of Indonesian Muslim youths' attitude towards halal cosmetic products: A case study in Jakarta. Asia Pacific Management Review, I-9. https://doi.org/I0.10I6/j.apmrv.2017.07.012

Briliana, V., \& Noviana, R. (2016). The antecedents and outcome of halal cosmetic products: a case study in jakarta indonesia, II(2), I-9.

Choudhury, M. A. (2018). The ontological law of Tawhid contra 'Shari'ahcompliance' in Islamic portfolio finance. International Journal of Law and Management, 60(2), 4I3-434. https://doi.org/IO.I I08/IJLMA-0I-20I7OOOI

Clarita, N. M. A., Zimbalist, S. B., \& Setiowati, R. (2020). Factors Impacting Customer Attitude toward Buying Halal Cosmetics in Jabodetabek. The Winners, 2I(I), 7-I4. https://doi.org/I0.2I5I2/tw.v2IiI.5873

Endah, N. H. (2014). Perilaku Pembelian Kosmetik Berlabel Halal oleh Konsumen Indonesia. Jurnal Ekonomi Dan Pembangunan, 22(I), II-25. https://doi.org/I0.I4203/JEP.22.I.2014.25-39

Farlina, N., Shafii, Z., \& Shahwan, S. (2015). Awareness and Perception of Muslim Consumers on Halal Cosmetics and Personal Care Products. International Journal of Business, Economics and Management, I(I), I-I4. https://doi.org/I0.I8488/journal.62/2015.2.I/62.I.I.I4

Febryan, \& Kelana, I. (2020). Kosmetik Halal Kian Digemari | IHRAM. Retrieved December 22, 2020, from https://ihram.co.id/berita/q740wf374/kosmetik-halal-kian-digemari

Ghozali, I., \& Latan, H. (2015). Partial Least Square, Konsep Teknik, dan Aplikasi menggunakan program SmartPLS 3.0 untuk Penelitian Empiris. Semarang: Undip Press.

Hanzaee, K. H., \& Ramezani, M. R. (20II). Intention to Halal Products In THe World Markets. Interdisciplinary Journal of Research in Business, I(May), I-7.

Hashim, A. J. C. M., \& Musa, R. (2013). Modeling the Effects on the Attitude of Young Adult Urban Muslim Women towards Halal Cosmetic Products: New Insights for Championing the Halal Economy. International Journal of Education and Research, I(7), I-8. 
Hashim, P., \& Mat Hashim, D. (2013). A review of cosmetic and personal care products: Halal perspective and detection of ingredient. Pertanika Journal of Science and Technology, 2I(2), 28I-292.

Hu, X., Lin, Z., \& Zhang, H. (2008). Trust Promoting Seals in Electronic Markets Trust Promoting Seals in Electronic Markets: An Exploratory Study of Their Effectiveness for Online Sales Promotion. Journal of Promotion Management, $\quad$ (I-2), $\quad$ I63-I80. https://doi.org/IO.I300/J057v09n0I

Ihwanudin, N., Maulida, S., Ilham Akbar Fatriansyah, A., Sari Rahayu, S., Nugroho, L., Widyastuti, S., ... Arzhi Jiwantara, F. (2020). Pengantar Perbankan Syariah (Konsep, Regulasi \& Praktis). Widina Bhakti Persada Bandung. Retrieved from www.penerbitwidina.com

Iqbal Fasa, M., Febrianty, M., Si Abd Kholik Khoerulloh, M., Arisa, A., Wiwik Utami, Ss., Ivan Rahmat Santoso, C., ... Anne Haerany, M. (2020). Eksistensi Bisnis Islami Di Era Revolusi Industri 4.0. Widina Bhakti Persada Bandung. Retrieved from www.penerbitwidina.com

Kaifi, B. A., Nafei, W. A., Khanfar, N. M., \& Kaifi, M. M. (2012). A MultiGenerational Workforce: Managing and Understanding Millennials, 7(24), 88-93. https://doi.org/I0.5539/ijbm.v7n24p88

Kamarulzaman, Y., Veeck, A., Mumuni, A. G., Luqmani, M., \& Quraeshi, Z. A. (20I5). Religion, Markets, and Digital Media : Seeking Halal Food in the U.S. https://doi.org/IO.I I77/0276I467I5622243

Kotler, P. (I994). Reconceptualizing marketing: An interview with Philip Kotler. European Management Journal, I2(4), 353-36I. https://doi.org/I0.I0I6/0263-2373(94)9002I-3

Kotler, P., \& Pfoertsch, W. (2007). Being known or being one of many: The need for brand management for business-to-business (B2B) companies. Journal of Business \& Industrial Marketing, 22(6), 357-362. https://doi.org/I0.II08/088586207I0780II8

Kurniawati, D. A., \& Savitri, H. (2019). Awareness level analysis of Indonesian consumers toward halal products. Journal of Islamic Marketing. https://doi.org/I0.II08/JIMA-I0-20I7-0I04

Larasati, A., Rahayu, S., Hati, H., \& Safira, A. (2018). Religiusitas dan Pengetahuan Terhadap Sikap dan Intensi Konsumen Muslim untuk Membeli Produk Kosmetik Halal, 8(April), I05-II4. 
IKONOMIKA

Volum 5, No 2 (2020)

https://doi.org/I0.15408/ess.v8i2.7459

Majid, M. B., Sabir, I., \& Ashraf, T. (2015). Consumer Purchase Intention towards Halal Cosmetics \& Personal Care Products in Pakistan. Global of Research in Business \& Management, $I(\mathrm{I}), 45-53$.

Mohd Nawawi, M. S. A., Abu-Hussin, M. F., Faid, M. S., Pauzi, N., Man, S., \& Mohd Sabri, N. (2019). The emergence of halal food industry in nonMuslim countries: a case study of Thailand. Journal of Islamic Marketing, II(4), 9I7-93I. https://doi.org/I0.II08/JIMA-05-20I8-0082

Morsing, M., \& Schultz, M. (2006). Corporate social responsibility communication: stakeholder information, response and involvement strategies. Business Ethics: A European Review, I5(4), 323-338. https://doi.org/I0.II I I/j.I467-8608.2006.00460.x

Mujahidin, M. (2020). The Potential Of Halal Industry In Indonesia To Support Economic Growth. Al-Kharaj: Journal of Islamic Economic and Business, 2(I), 77-90. https://doi.org/I0.24256/kharaj.v2iI.I433

Mukhtar, A., Butt, M. M., Mukhtar, A., \& Butt, M. M. (2012). religiosity Intention to choose Halal products: the role of religiosity. https://doi.org/I0.II08/I759083I2II2325I9

Nugroho, L. (2020a). Konsep Ekonomi dan Perbankan dalam Islam. In Pengantar Perbankan Syariah (Ist ed., Vol. I, pp. I-26). Widina Bhakti Persada bandung. https://doi.org/I0.1017/CBO978I I07415324.004

Nugroho, L. (2020b). Pengetahuan Konsumen Vis A Vis Perubahan Perilaku Konsumen Pada Era Digital. In Perilaku Konsumen dan Perkembangannya di Era Digital (pp. 65-77). Widina Bhakti Persada.

Nugroho, L., Harnovinsah, Putra, Y. M., \& Prinoti. (2020). Analysis of Comparison of Islamic Banks with Financial Technology (Fintech) In Disbursements of Micro-Financing Based on Requirements, Services Speed and Margin. Journal of Islamic Economics \& Social Science-JIESS, I(I), IIO.

Nugroho, L., Hidayah, N., \& Badawi, A. (2019). Discourses of Sustainable Finance Implementation in Islamic Bank (Cases Studies in Bank Mandiri Syariah 2018). International Journal of Financial Research, IO(6), I08-II7. https://doi.org/I0.5430/ijfr.vIOn6pI08

Ordun, G. (2015). Millennial (Gen Y) Consumer Behavior Their Shopping Preferences and Perceptual Maps Associated With Brand Loyalty. Canadian Social Science, II(4), I-I6. https://doi.org/I0.3968/pdf_294 
Rahayu, A. C., \& Tendi. (2019). Alhamdulillah, pemain kosmetik akui tren penjualan terus naik usai beri label halal. Retrieved December I7, 2020, from https://industri.kontan.co.id/news/alhamdulillah-pemain-kosmetik-akuitren-penjualan-terus-naik-usai-beri-label-halal

Rohmatun, K. I., \& Dewi, C. K. (2017). Pengaruh Pengetahuan Dan Religiusitas Terhadap Niat Beli Pada Kosmetik Halal Melalui Sikap, I(I), 27-35.

Rowley, J. E. (2002). Reflections on customer knowledge management in ebusiness. Qualitative Market Research: An International Journal, 5(4), 268280. https://doi.org/IO.I I08/I35227502I0443227

Saeed, M., Ahmed, Z. U., \& Mukhtar, S.-M. (200I). International Marketing Ethics from an Islamic Perspective: A Value-Maximization Approach. Journal of Business Ethics, 32(2), I27-I42.

Sekaran, U., \& Bougie, R. (2016). Research Methods For Business: A Skill Building Approach. John Wiley \& Sons. Retrieved from https://books.google.co.id/books?hl=en\&lr=\&id=Ko6bCgAAQBAJ\&oi=f nd\&pg $=$ PAI $\&$ dq $=$ Research + methods + for + business: + A + skill + building + approach\&ots=2B5QZ5I_mP\&sig=bfjSuyhI9EupVWN6CXBsCoJLb4\&redir_esc ${ }_{\mathrm{y}} \#_{\mathrm{v}}={ }_{\text {onepage }} \mathrm{q}=$ Research methods for business $\% 3 \mathrm{~A}$ A skill building

Shafii, Z., \& Wan Siti Khadijah, W. M. N. (2012). Halal traceability framework for halal food production. World Applied Sciences Journal, I7( I2), I-5.

Shirin Asa, R. (20I7). Malaysian Halal Certification: It'S Religious Significance and Economic Value. Jurnal Syariah, 25(I), I37-I56. https://doi.org/I0.22452/js.vol25noI.7

Sudirman, A. (Acai), Alaydrus, S. (Syafika), Rosmayati, S. (Siti), Syamsuriansyah, S. (Syamsuriansyah), Nugroho, L. (Lucky), Arifudin, O. (Opan), ... Rijal, K. (Khairul). (2020). Perilaku Konsumen Dan Perkembangannya Di Era Digital. Widina Bhakti Persada Bandung. Retrieved from www.penerbitwidina.com

Suki, N. M., \& Salleh, A. S. A. (2018). Mediating effect of Halal image on Muslim consumers' intention to patronize retail stores: some insights from Malaysia. Journal of Islamic Marketing, 9(2), 338-355.

Sukmadilaga, C., Fitrijanti, T., Nugroho, L., \& Utami, W. (2017). International Journal of Economics and Financial Issues The Urgency of Allignment Islamic Bank to Increasing the Outreach (Indonesia Evidence). International Journal of Economics and Financial Issues, 7(4), 283-29I. Retrieved from 
http:www.econjournals.com

Tulloch, J. C., \& Zinn, J. O. (20II). Risk, health and the media. Health, Risk \& Society, I3(I), I-I6. https://doi.org/I0.I080/I3698575.20I0.543I23

Wallace, J. (2018). Modelling Contemporary Gatekeeping: The rise of individuals, algorithms and platforms in digital news dissemination. Digital Journalism, $6(3)$,

274-293. https://doi.org/I0.1080/2I6708 I I.2017.1343648

Wang, Y., \& Hazen, B. T. (2016). Consumer product knowledge and intention to purchase remanufactured products. International Journal of Production Economics, I8I, 460-469. https://doi.org/I0.I0I6/j.ijpe.20I5.08.03I

Worthington, E. L., Wade, N. G., Hight, T. L., Ripley, J. S., McCullough, M. E., Berry, J. W., ... O'Connor, L. (2003). The Religious Commitment Inventory-10: Development, refinement, and validation of a brief scale for research and counseling. Journal of Counseling Psychology, 50(I), 84-96. https://doi.org/I0.1037/0022-0167.50.I.84

Yanti, I. (2018). Analisis Pengaruh Faktor Psikologis dan Religiusitas Perilaku Muslimah Kota Medan terhadap Konsumsi Kosmetik Halal dan Baik. AtTawassuth, 3(2), 293-3I3.

Yoyok, \& Hidayat, A. (20I8). Industri kosmetik dan makanan bersiap menghadapi pertumbuhan pasar halal. Retrieved December 18, 2020, from https://industri.kontan.co.id/news/industri-kosmetik-dan-makananbersiap-menghadapi-pertumbuhan-pasar-halal

Yulianti, R. (2016). Pengaruh Minat Masyarakat Aceh terhadap Keputusan Memilih Produk Perbankan Syariah di Kota Banda Aceh. Jurnal Dinamika Akuntansi Dan Bisnis, $2(\mathrm{I}), \quad$ I4-28. https://doi.org/I0.248I5/jdab.v2iI.3599

Yulianto, A. (20I7). BPJPH Harus Segera Kembangkan Literasi Halal I Republika Online. Retrieved December 22, 2020, from https://republika.co.id/berita/dunia-islam/islamnusantara/I7/I0/I2/oxohuv396-bpjph-harus-segera-kembangkan-literasihalal 
Antecedents and Consequences of Muslim Millennials Attitude Towards Halal Personal Care Products

Febrina Mahliza ${ }^{1}$, Lucky Nugroho ${ }^{2}$, Anees Jane $\mathrm{Ali}^{3}$ 